\title{
PENINGKATAN KEDISIPLINAN SISWA SMK NEGERI 2 SOE MELALUI PENGEMBANGAN PRESENSI ONLINE TERHUBUNG SMS GATEWAY DAN WHATSAPP
}

\author{
Vera Rosalina Bulu, ${ }^{1, *}$, Diana Yani Fallo ${ }^{2}$, Asti Yunita Benu ${ }^{3}$ \\ ${ }^{1}$ Program Studi Pendidikan Guru Sekolah Dasar, Universitas Citra Bangsa \\ ${ }^{2,3}$ Program Studi Pendidikan Informatika, Universitas Citra Bangsa \\ Jalan Manafe No 17, Kayu Putih \\ Email Korespondensi: *veraros0451@gmail.com
}

Received : November 17, 2020 ; Accepted : December 29, 2020 ; Published : January $1^{\text {st }}, 2021$

\begin{abstract}
Abstrak
Presensi online terhubung whatsapp dan SMS gateway akan mempermudah guru dan orang tua dalam mengontrol kehadiran siswa dengan cepat dan akurat. Implementasi presensi online terhubung whatsapp dan SMS gateway dilberlakukan pada siswa SMK Negeri 2 Soe. Sistem ini bertujuan memberikan informasi berkaitan dengan kehadiran siswa SMK Negeri 2 Soe setiap hari sampai pada rekapan setiap bulan. Metode yang digunakan metode Rapid Application Development (RAD). Rapid Application Development (RAD) adalah suatu metode pengembangan perangkat lunak dengan pendekatan berorientasi objek terhadap pengembangan sistem. Ada 3 tahapan dalam program kemitraan masyarakat ini yaitu tahap perencanaan yaitu tahap pengambilan data yang berkaitan dengan pengembangan sistem, tahap perancangan sistem termasuk didalamnya perekaman sidik jari dan uji coba program presensi online serta tahap penerapan dimana siswa menggunakan presensi sidik jari ini secara shift sesuai jam masuk dan keluar sekolah siswa. Hasil yang diperoleh pengguna yaitu siswa, guru dan orang tua dapat dengan mudah dan cepat merekap kehadiran siswa SMK Negeri 2 Soe sehingga dalam proses pengontrolan kehadiran siswa lebih mudah dan berdampak pada kedisiplinan siswa SMK Negeri 2 yang semakin meningkat.

Kata Kunci: Presensi online, Kedisiplinan Siswa
\end{abstract}

\begin{abstract}
Online Attendance list connected to whatsapp and SMS gateway will make teachers and parents to be easier in controlling student attendance quickly and accurately. This kind of attendance list is applied at SMK Negeri 2 Soe. This system aims to provide information related to the students attendance of SMK Negeri 2 Soe every day until the recap every month. The method used is the Rapid Application Development (RAD) method. Rapid Application Development (RAD) is a software development method with an object-oriented approach to system development. There are 3 stages in this community partnership program, namely the planning stage for the data retrieval related to the development of the system, the stage of system design including fingerprint recording and online attendance list program trials as well as the implementation stage where students use this fingerprint press on a shift according to before and after school hour.. The results obtained shows that students, teachers and parents can easily and quickly increase the students'attendance of SMK Negeri 2 Soe. The process of controlling student attendance is easier and it has an impact on the discipline of SMK Negeri 2 students which is increasing.
\end{abstract}

Keywords : Online prestige, student discipline 


\section{Pendahuluan}

Pendidikan menjadi salah satu tolak ukur untuk menciptakan sumber daya manusia yang berkualitas di masa depan. Sumber daya manusia yang berkualitas tidak hanya dilihat dari pengetahuan tetapi juga dari sikap (karakter) dan keterampilan. Oleh karena itu, pendidikan saat ini berusaha untuk menyeimbangkan pengetahuan, sikap (karakter) dan keterampilan. Salah satu bagian yang sedang gencar - gencarnya dilakukan di sekolah yaitu pendidikan karakter untuk membantu membentuk karakter siswa yang sesuai dengan kepribadian bangsa.

Kedisiplinan menjadi salah satu karakter dasar yang dipelajari di sekolah untuk membentuk siswa - siswa menjadi pribadi yang memiliki kontrol diri untuk berperilaku yang taat moral sehingga tidak mudah terpengaruh dengan perkembangan jaman sebaliknya dapat memberikan pengaruh dan memberikan warna tersendiri terhadap perkembangan tersebut. Pembiasaan karakter disiplin membuat siswa memperoleh peningkatan prestasi. Tujuan dari kedisipilinan pada anak yaitu memberikan pemahaman dan mengarahkan anak tentang perilaku yang baik dan benar sehingga anak mampu membedakan tentang perilaku yang baik dan benar[1]. Kedisiplinan sangat penting diterapkan untuk membentuk kebiasaan yang teratur maupun ketertiban dimanapun berada[2].

Kedisiplinan tidak hanya membentuk perilaku siswa namun juga memberikan dampak positif terhadap hasil belajar siswa. Siswa dengan kedisiplinan belajar yang baik akan mampu bekerja dengan kapasitas yang dimilikinya untuk mencapai hasil belajar yang baik[3]. Hal senada juga yang menyatakan bahwa kedisiplinan belajar mempengaruhi hasil belajar peserta didik[4].

Berkaitan dengan kedisiplinan, terdapat 4 indikator kedisiplinan yaitu ketaatan terhadap waktu belajar, ketaatan terhadap tugas belajar, ketaatan terhadap penggunaan fasilitas belajar dan ketaatan menggunakan waktu datang dan pulang[5]. Dalam program kemitraan masyarakat ini, akan berfokus pada indikator ketaatan menggunakan waktu dating dan pulang sebab hal tersebut mempengaruhi indikator lain diantaranya mempengaruhi ketepatan waktu belajar, ketaatan mengerjakan tugas dan sebagainya.

Disiplin terjadi dan terbentuk sebagai hasil dan dampak proses pembinaan cukup panjang yang dilakukan sejak dari dalam keluarga dan berlanjut dalam pendidikan di sekolah. Oleh sebab itu, perilaku disiplin tidak hanya menjadi tanggung jawab guru di sekolah yang membuat peraturan di sekolah tetapi juga menjadi tanggung jawab orang tua di rumah. Di sekolah guru menjadi pengendali siswa, namun orang tua menjadi panutan dasar anak anak dalam mendisiplinkan diri.

SMK Negeri 2 Soe adalah SMK Model di Kota Soe. Sebagai sekolah model, SMK Negeri 2 Soe harusnya menjadi model dalam 3 aspek yaitu pengetahuan, sikap dan keterampilan. Sekolah telah memberikan aturan mengenai jam masuk dan keluar serta pemberian punishment bagi siswa yang terlambat namun seringkali tidak diterima orang tua. Proses pencatatan kehadiran secara manual tidak memberikan informasi yang cukup bagi orang tua berkaitan dengan kehadiran siswa di sekolah. Melihat solusi yang diberikan sekolah belum dapat mengatasi masalah tersebut maka solusi lain dapat dilakukan dengan menerapkan presensi online yang dapat memberikan informasi dengan cepat dan mudah kepada orang tua dan guru mengenai kehadiran siswa. Presensi yang dimaksud yaitu presensi online berbasis whatsapp atau SMS gateway kepada orang tua dan wali kelas.

Ilmu pengetahuan dan teknologi sekarang ini telah memberikan dampak yang cukup signifikan terhadap dunia pendidikan salah satunya dengan penerapan presensi yang memanfaatkan teknologi di sekolah dan kampus[6]. Berkaitan dengan pemanfaatan sistem presensi online, penggunaan sistem presensi online dapat membantu mempermudah pengelolaan data presensi siswa sehingga dapat membantu guru maupun orang tua untuk melakukan evaluasi terhadap kehadiran siswa, termasuk sebagai upaya peningkatan mutu 
pendidikan yang didukung oleh efektifitas sistem administrasi[7]. Hal ini tentunya dapat mengurangi tindakan ketidakdisiplinan siswa karena orang tua juga dapat mengontrol siswa dan mengurangi kesalahpahaman orang tua atas punishment yang diberikan kepada siswa. Selain itu, data kehadiran siswa pun dapat diberikan secara konsisten kepada orang tua dan wali kelas sehingga orang tua dapat mengikuti perkembangan sikap disiplin siswa di sekolah. Dengan adanya presensi online maka akan mengurangi kesalahan dalam merekap kehadiran[8].

Melihat permasalahan tersebut, penulis bermaksud untuk mengadakan program kemitraan masyarakat di Sekolah Menengah Kejuruan Negeri 2 Soe, untuk meningkatkan kedisiplinan siswa dalam hal kehadiran siswa di sekolah dan kelas dengan mengembangkan aplikasi presensi online terhubung whatsapp orang tua dan wali kelas, sehingga pengontrolan mengenai kehadiran siswa tidak hanya dilakukan oleh guru di sekolah tetapi juga oleh orang tua.

Permasalahan prioritas yang dialami oleh SMK Negeri 2 Soe sebagai salah satu sekolah menengah kejuruan model di Kota Soe yaitu masalah kedisiplinan siswa yang kurang dikontrol baik oleh guru maupun orang tua. Adapun dampak dari kedisiplinan siswa yang kurang dikontrol oleh guru dan orang tua, yaitu terciptanya masalah - masalah sebagai berikut:

a. Berdasarkan wawancara dengan wakasek bidang kemahasiswaan dan guru BK, kurangnya informasi mengenai kehadiran siswa di sekolah (presensi) kepada orang tua membuat orang tua menyalahkan sekolah atas punishment yang diberikan kepada siswa sebagai bentuk pelanggaran kedisiplinan.

b. Berdasarkan observasi dan wawancara dengan wakasek bagian kemahasiswaan dan beberapa guru Selama berdirinya sekolah ini data base kehadiran siswa tidak tersimpan dengan baik dan hanya menjadi informasi bagi guru saja dan dilaporkan kepada orang tua di akhir semester.

c.

Berdasarkan masalah terhadap kedisiplinan di SMK Negeri 2 Soe, maka penulis menawarkan beberapa solusi untuk masalah tersebut antara lain:

a. Mengembangkan program presensi online terhubung whatsapp orang tua dan guru, sehingga informasi kehadiran siswa di sekolah tidak hanya diketahui oleh guru, tetap juga oleh orang tua siswa sehingga memudahkan untuk pengontrolan oleh guru dan orang tua.

b. Data base kehadiran siswa di SMK Negeri 2 Soe dapat tersimpan dengan baik

\section{Metode}

Penelitian ini menggunakan metode Rapid Application Development (RAD). Rapid Application Development (RAD) adalah suatu metode pengembangan perangkat lunak dengan pendekatan berorientasi objek terhadap pengembangan sistem. Tim Pengabdian menggunakan metode ini Menurut[6] RAD merupakan suatu metode pengembangan perangkat lunak dengan pendekatan berorientasi objek (object oriented approach) terhadap pengembangan sistem. Metode ini bertujuan untuk mempersingkat waktu dalam perencanaan, perancangan dan penerapan suatu sistem bila dibandingkan dengan metode tradisional. Lebih lanjut, dikatakan bahwa siklus RAD dengan 3 (tiga) fase dalam perencanaan, perancangan dan penerapan sistem yang melibatkan analis dan pengguna.

Berdasarkan uraian terseburt, maka dilakukan tahapan dalam pengabdian masyarakat ini yaitu perencanaan pengembangan sistem, perancangan sistem serta penerapan sistem yang melibatkan tim pengabdian dan SMK Negeri 2 Soe. 


\subsection{Perencanaan Pengembangan Sistem}

Pada tahap perencanaan tim pengabdian bertemu dengan pengguna dalam hal ini SMK Negeri 2 Soe untuk menyampaikan tujuan dan mengambil data - data yang diperlukan dalam rangka pengembangan program presensi online terhubung SMS Gateway dan Whatsapp antara lain data siswa SMK Negeri 2 Soe, Sidik Jari Siswa, No Handphone orang tua siswa dan No handphone wali kelas.

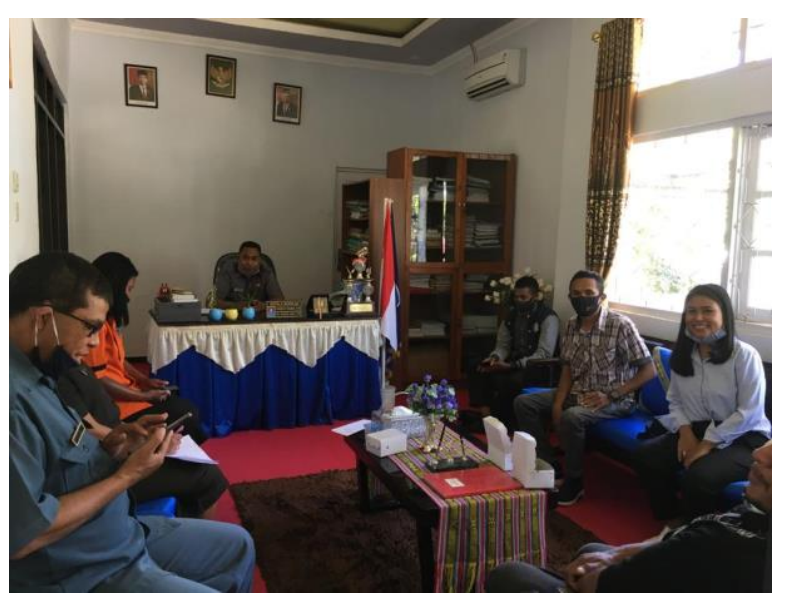

Gambar 1. Pertemuan Awal dengan Pihak Sekolah untuk Pengambilan Data Awal

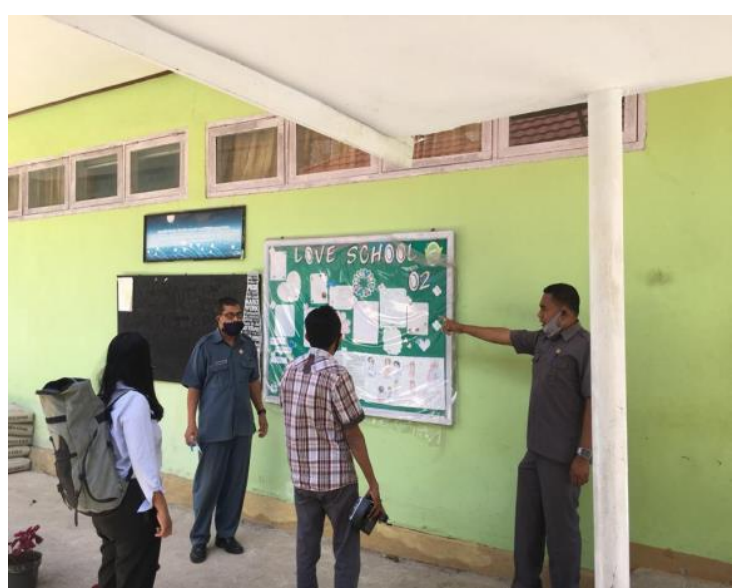

Gambar 2. Kepala Sekolah Menunjukan Lokasi Menggantung Mesin Sidik Jari

\subsection{Perancangan Sistem Presensi Online Terhubung Whatsapp dan SMS Gateway}

Pada tahap perancangan, Tim pengabdian masyarakat merancang program presensi online. Tahap ini dilakukan selama 3 bulan. Pada tahap ini, tim pengabdian masyarakat juga melakukan uji coba presensi online terhubung SMS Gateway dan Whatsapp serta evaluasi dan revisi terhadap hasil uji coba tersebut. Uji coba presensi online dilakukan di kelas X, XI dan XII jurusan TKJ. Pada tahap ini tim pengabdian mengambil sidik jari dari siswa di kelas $\mathrm{X}$, XI dan XII jurusan TKJ, kemudian berdasarkan data tersebut tim pengabdian melakukan uji coba presensi online tersebut, berdasarkan hasil uji coba tersebut didapatkan revisi yaitu presensi online hanya membaca NIS dari siswa dan tidak membaca nama siswa, sehingga tim pegabdian perlu menginput nama siswa pada absen tersebut. Selanjutnya, tim pengabdian bekerjasama dengan sekolah untuk melakukan sosialisasi terlebih dahulu kepada guru. Informasi dari guru kemudian diteruskan kepada orang tua dan siswa secara online melalui grup whatsapp yang tersedia.

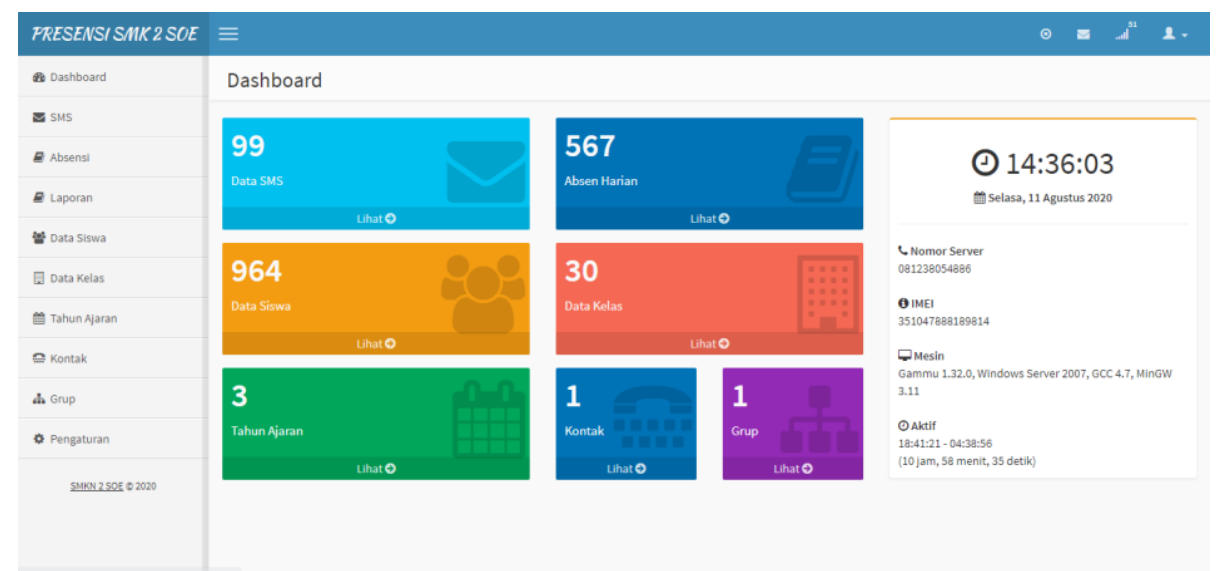

Gambar 3. Tampilan Depan Presensi Online Terhubung Whatsapp dan SMS Gateway 

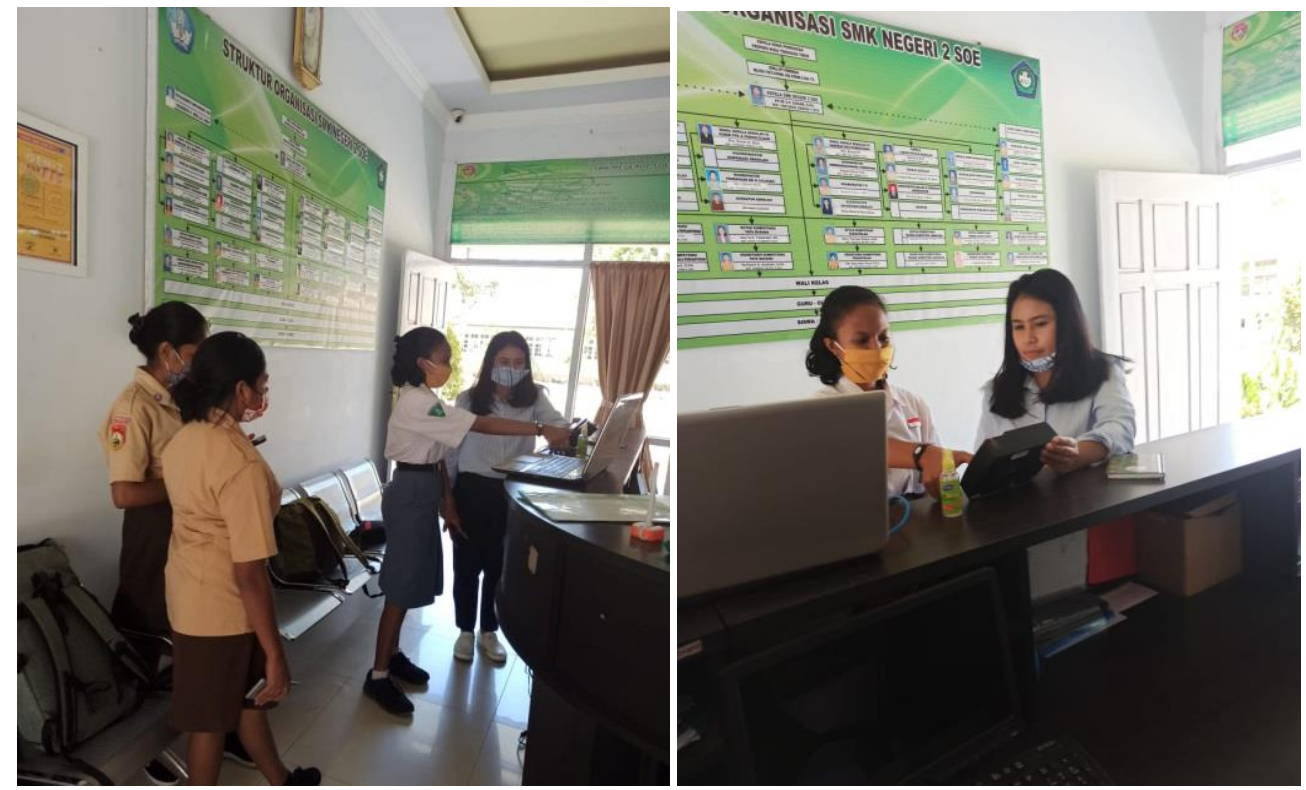

Gambar 4. Pengambilan Sidik Jari Untuk Uji Coba

\subsection{Penerapan Sistem Presensi Online Terhubung Whatsapp dan SMS Gateway}

Penerapan sistem presensi online dilaksanakan pada siswa SMK Negeri 2 Soe untuk melihat jam masuk dan keluar siswa serta melaporkan kepada wali kelas dan orang tua dalam rangka pengontrolan kedisiplinan siswa sehingga terjadi peningkatan kedisiplinan. Data sidik jari akan masuk ke dalam database diteruskan oleh operator sekolah melalui SMS gateway dan whatsapp kepada wali kelas dan orang tua yang memiliki handphone. Selain itu, data absen ini dapat dijadikan rekapan laporan kehadiran siswa di sekolah. Perangkat keras yang digunakan yaitu mesin sidik jari X $100 \mathrm{C}$, satu paket komputer. Perangkat lunak yang digunakan yaitu pemrograman PHP.

Adapun cara kerja dari sistem presensi online tersebut yaitu siswa melakukan scan masuk melalui fingerprint pada waktu yang telah ditentukan yaitu pkl 07:00-07:30. Kemudian admin menarik data dari mesin fingerprint kedalam bentuk Ms. Excel setelah semua siswa selesai melakukan scan. Setelah itu admin akan memasukannya kedalam program dengan mengupload file Ms. Excel tersebut. Setelah berhasil di upload, program akan secara otomatis memberitahu orangtua dan wali kelas tentang kehadiran siswa pada hari tersebut. Pengambilan sampel data dilakukan dengan melibatkan siswa SMK Negeri 2 Soe dengan memperhatikan protokol kesehatan, dimana sebelum dan sesudah merekam sidik jari harus siswa diwajibkan menggunakan hand sanitiser. Setiap siswa diminta untuk merekam sidik jari sebanyak 3 kali. Data sidik jari kemudian disimpan ke dalam database sidik jari untuk dijadikan pembanding sidik jari siswa pada saat masuk dan keluar sekolah. Berikut cara kerja presensi online terhubung whatsapp dan SMS gateway 


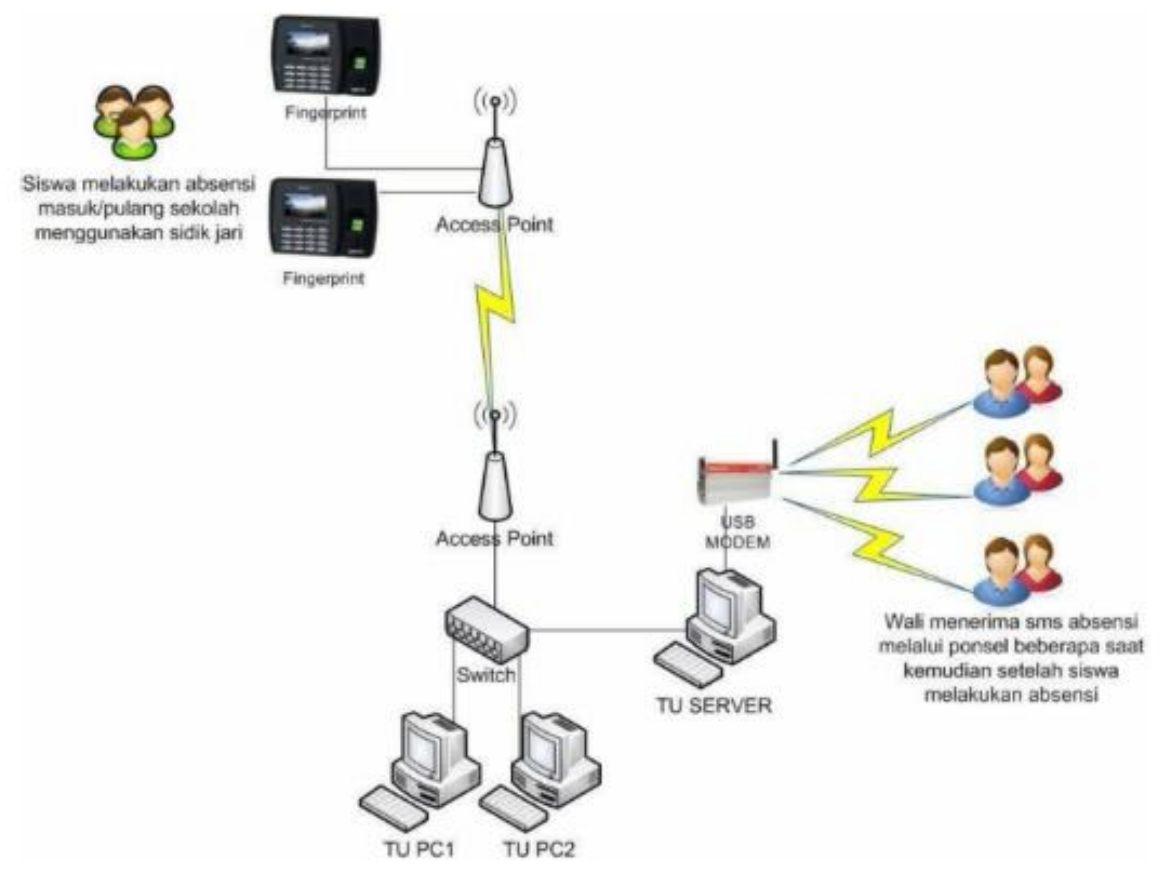

Gambar 5. Alur Presensi Online Terhubung Whatsapp Dan SMS Gateway

\subsection{Luaran Pengabdian Masyarakat}

Luaran dari kegiatan pengabdian masyarakat ini yaitu peningkatan kedisiplinan siswa SMK Negeri 2 Soe melalui pengembangan presensi online terhubung SMS Gateway dan whatsapp kepada orang tua dan wali kelas.

\section{Hasil dan Pembahasan}

Tujuan dari kegiatan pengabdian yang telah dilaksanakan yaitu pengembangan dan implementasi presensi online terhubung whatsapp dan SMS Gateway kepada orang tua dan wali kelas siswa untuk meningkatkan kedisiplinan siswa SMK Negeri 2 Soe. Presensi dilakukan oleh siswa yang mendapat jadwal belajar pagi pukul 07.00 dan keluar pukul 12.00 dan siswa yang mendapat jadwal belajar siang pukul 13.00 dan keluar pukul 17.00. Tim pengabdian masyarakat dan sekolah menyepakati untuk memberikan toleransi waktu kehadiran selama 30 menit untuk setiap jam masuk dan keluar. Kehadiran dan ketidakhadiran siswa akan direkam pada database yang ada untuk diteruskan kepada wali kelas dan orang tua siswa oleh operator sekolah.

Berdasarkan survey yang dilakukan kepada pengguna yaitu siswa, sekolah dan guru merasa terbantu dengan adanya program presensi online antara lain siswa dapat mengetahui jumlah kehadiran dan ketihadiran selama sebulan sehingga dapat dijadikan bahan evaluasi bagi siswa itu sendiri. Bagi guru, dengan adanya presensi online dapat membantu guru dengan mudah dan cepat melakukan rekapan kehadiran siswa sehingga mudah untuk dikontrol dan bagi orang tua dapat dengan mudah mengetahui rekapan kehadiran siswa per hari sampai per bulan sehingga kehadiran siswa di sekolah juga dapat dikontrol oleh orang tua. Lebih lanjut, dengan adanya pengembangan sistem presensi online terhubung whatsapp dan SMS gateway ini membuat kedisiplinan siswa menjadi lebih baik dari sebelumnya. Hal ini sejalan dengan temuan yang menyatakan bahwa penggunaan presensi online terhubung SMS gateway kepada orang tua dapat memudahkan sekolah dalam memberikan laporan akademik siswa secara konsisten[4]. Temuan lain, yang telah menerapkan presensi online 
untuk pegawai menunjukan bahwa Implementasi sistem informasi presensi sidik jari (fingerprint) online terbukti memiliki korelasi positif terhadap disiplin pegawai yaitu tingkat kedisiplinan pegawai semakin baik (meningkat)[10][11]. Presensi online dapat merekam dengan baik kehadiran dan menghindari kesalahan pencatatan oleh karena human error [12].

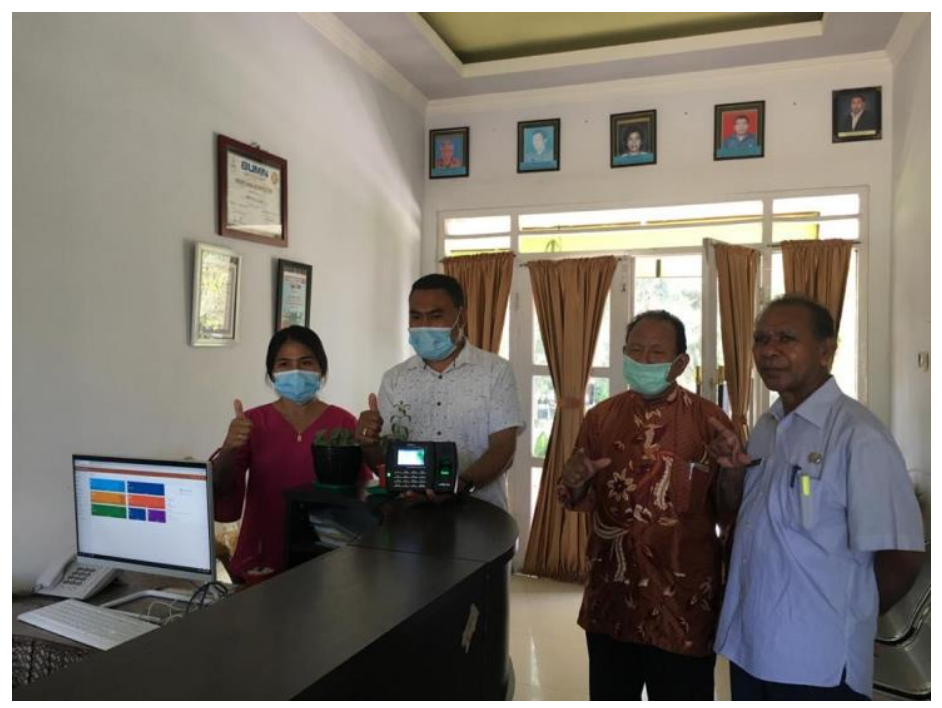

Gambar. 6 Penyerahan Program Presensi Online Kepada Pihak Sekolah.

Adapun kelebihan dari progam presensi online terhubung whatsapp dan SMS gateway yaitu dapat membantu pihak sekolah menyalurkan informasi baik kehadiran siswa dan undangan rapat dengan mudah kepada pihak yang terlibat antara lain wali kelas, orang tua dan guru, mempermudah sekolah dalam membuat laporan kehadiran siswa setiap bulan serta mempermudah sekolah menyimpan data kehadiran siswa dalam sistem sehingga tidak mudah hilang. Selanjutnya, kekurangan dari progam presensi online terhubung whatsapp dan SMS gateway yaitu program ini tidak dapat diimplementasikan dengan baik pada masa pandemi covid - 19 sebab siswa banyak diliburkan dari sekolah dan dapat menjadi salah satu sarana penyebaran covid-19 jika digunakan tidak sesuai protokol kesehatan.

\section{Kesimpulan}

Berdasarkan kegiatan program kemitraan masyarakat yang dilakukan, didapatkan kesimpulan bahwa dengan adanya pengembangan presensi online terhubung SMS gateway dan whatsapp kepada wali kelas dan orang tua siswa membantu orang tua dan wali kelas untuk merekap dan mengontrol kehadiran siswa SMK Negeri 2 Soe sehingga kedisiplinan siswa semakin baik bila dibandingkan dengan bulan - bulan sebelum implementasi program presensi online tersebut.

\section{Daftar Pustaka}

[1] Wahyuni, Peningkatan Kedisiplinan Siswa Melalui Teknik Kontrak Perilaku di TK ABA PAKIS, Jurnal Student UNY, vol 5, no 3, pp. 270 - 278, 2016.

[2] Derta, S., "Desain Sistem Informasi Kedisiplinan Siswa di Sekolah Menegah Kejuruan Negeri 1 Bukittinggi”, Jurnal Jaringan Sistem Informasi Robotik, vol. 4, no. 2. pp. 34 48, 2020.

[3] Rezki, N., Taufik \& Ifdil., "Konsep Diri dan Kedisiplinan Belajar Siswa. Jurnal Educatio, Jurnal Pendidikan Indonesia", vol. 3, no. 2, pp. 85 - 91, April 2017.

[4] Wirantasa, "Pengaruh Kedisiplinan Belajar Siswa Terhadap Prestasi Belajar Matematika, Jurnal Formatif', vol. 7, no. 1, pp. 83 - 95, 2017. 
[5] Retong, M.L., "Peningkatan Kedisiplinan Siswa Melalui Layanan Bimbingan Kelompok, Jurnal Gema Wiralodra", vol. 10, no. 1, pp. 331 - 342, 2019.

[6] Putra, D.S. \& Fauziyah, A, "Perancangan Aplikasi Presensi Dosen Realtime Dengan Metode Rapid Application Development (RAD) Menggunakan Fingerprint Berbasis Web", Jurnal Informatika: Jurnal Pengembangan IT (JPIT), vol.03, no.02, pp. 167 $171,2018$.

[7] Susanto, E.,Perdana, D.,Irawan, A.I.,Yasirandi, R., "Pengembangan Sistem Presensi Menggunakan Quick Response Code Dinamis untuk Madrasah Aliyah Al Mukhlisin Bandung”, Jurnal Rekayasa Elektrika, vol. 15, no. 2, pp. 139-144, Agustus 2019.

[8] Wantoro, "Pengembangan Sistem Presensi dan Kedisiplinan Dosen Terhadap Biaya Operasional Perguruan Tinggi", Jurnal TEKNOINFO, vol. 10, no. 1, pp. 1 - 5. 2016.

[9] Jaikumar, K., Kumar, M.S., Rajkumar, S., Sakhtivel, A., "Fingerprint Based Student Attendance System With SMS Alerts To Parents". IJRET: International Journal of Research in Engineering and Technology, vol 4, no 2, pp. 293 - 297, 2015.

[10] Larasati,D, "Korelasi Implementasi Sistem Presensi Sidik Jari (Fingerprint) Online dan Kedisiplinan Terhadap Perubahan Perilaku Kerja Pegawai”, Jurnal Strategi dan Bisnis. vol. 4, no. 1, pp. 1-20, 2016.

[11] Setyawan, R.A, "Pengembangan Sistem Presensi Mahasiswa Elektronik Berbasis RFID”, Jurnal EECCIS, vol. 9, no. 2, pp.131-137, 2015.

[12] Haq, M.S, "Pengembangan Aplikasi Presensi Pegawai Berbasis Fingerprint", Jurnal Dinamika, Manajemen Pendidikan, vol.1, no. 1, pp. 34-40, 2016. 